\title{
PERSPECTIVE AND POLITENESS IN FINNISH REQUESTS ${ }^{1}$
}

\author{
Elizabeth Peterson
}

\begin{abstract}
This study makes use of elicited request speech act data in Finnish to view variability of personal perspective and T/V forms across a variety of situations. The speakers exhibited a great deal of congruency when they were scripted as addressing someone familiar, being in a position of equal or higher status than the interlocutor, and when the request was considered a low imposition. In such situations, speakers tended to use a second person perspective, with informal T/V forms. The Finnish T-forms were found to be the default form, showing up in half of the request utterances. The Finnish V-forms showed up in only 10 percent of the requests. A variationist analysis using Varbrul complemented the main findings, but was found to not be a reliable tool for elicited pragmatic data, using sociopragmatic factors as independent variables.
\end{abstract}

Keywords: Perspective; Forms of address; Finnish; Requests; Speech acts; Pragmatic variation.

\section{Introduction}

Systems of address are a key area in demonstrating social relations and how those relations are expressed through language. Systems of address are not only culturally and socially bound, but vary according to situation - who is present, the level of formality, how well the speakers knows the addressee, and so on. This variability presents a challenge for researchers who wish to gain empirical, quantitative evidence reflecting how people in a given situation say what to whom. This study, based on reported speech act data in Finnish, strives to describe variation in Finnish requests by offering analyses of a collection of data entailing several different social parameters, including variation in the power and social distance relations between speakers, the rate of imposition (see Brown and Levinson 1978/1987), and the requestive goal (see Varghese and Billmyer 1996). The article focuses on variation in the request perspective, as well as exploring the pragmatic choice of whether to address someone with an informal or a formal form of address (ie, a T/V form, as per Brown and Gilman 1960).

The request speech acts that are analyzed in the study were elicited from oral questionnaires in which the speakers, all native speakers of Finnish living in the Helsinki area, made requests in response to scripted prompts.

\footnotetext{
${ }^{1}$ I thank Kati Leivo for reading an early version of this paper, as well as an anonymous reviewer and the editor of this journal for their careful reading and suggestions.
} 


\subsection{Perspective in Finnish}

There are three ways of expressing personal perspective in Finnish: Through personal pronouns, through verbal person marking, and through possessive suffixes (Helasvuo and Laitinen 2006; VISK 2008). The system for marking person on the subject pronouns and verbs is shown Table 1.

Table 1: Verbal person marking according to Sulkala and Karjalainen (1992: 332; adapted from Helasvuo and Laitinen 2006: 173)

\begin{tabular}{llll}
\hline Active & singular & 'go' & 'take' \\
\hline & 1. (minä) & menen & otan \\
\hline 2. (sinä) & menet & otat \\
& 3. (hän) & menee & ottaa \\
\hline plural & & \\
\hline 1. (me) & menemme & otamme \\
& 2. (te) & menette & otatte \\
& 3. (he) & menevät & ottavat \\
\hline Passive: & & mennään & otetaan \\
\hline
\end{tabular}

Person can be marked on the verb in Finnish, as indicated through bold lettering in the verb forms in Table 1 . The subject pronouns are presented in parentheses to indicate their optionality (ie, Finnish is a so-called "pro-drop" language). In standard Finnish the preferred form is to suppress the pronoun and to mark person only on the verb. In colloquial spoken Finnish, however, a preference has been shown for retaining the subject pronoun, often in a truncated form in the first and second person, especially in informal situations (Lappalainen 2004, 2006a and b; VISK 2008 §107). An absence of the subject pronoun has a clear social meaning, for example reflecting the formality of a situation (Helasvuo and Laitinen 2006: 179). Finnish also has several means of describing activity of one's own or someone other without expressing the agent explicitly. These are the passive, which is shown in Table 1, the plural form, and the third person singular generic (Muikku-Werner 1993).

In their work on cross-cultural speech act behavior, Blum-Kulka et al. (1989) describe four ways in which person perspective is used in making a request. These are speaker oriented, hearer oriented, inclusive (self) oriented, and impersonal. The use of a hearer oriented perspective emphasizes the agent, whereas a speaker oriented perspective emphasizes the recipient. The issue of agency or recipient is avoided by using an inclusive "we," or an impersonal perspective (for example, Would it be possible to ...) (Blum-Kulka et al. 1989: 58). The request perspective qualifies as one of Blum-Kulka et al's "universal" categories, even though a given language may prefer different strategies.

Accounts of perspective in Finnish tend to focus on grammatical, rather than pragmatic properties (but see Muikku-Werner 1992 and Helasvuo and Laitinen 2006). According to Muikku-Werner (who cites Blum-Kulka et al. 1989), the choice of person in a given construction in Finnish affects a favorable outcome, serving to make a speech event either more open or more inclusive. For example, Muikku-Werner states that a general construction (such as the third person, or impersonal) is an indicator of negative politeness, whereas the use of an inclusive pronoun such as me 'we' is a form of positive politeness (Muikku-Werner 1993: 179). 


\subsection{Forms of second person address in Finnish}

As mentioned previously, person in Finnish shows on pronouns, verbs, and in possessive forms. Any of these forms, therefore, also show either formal or informal markings in the second person.

According to the literature on forms of address in Finnish, the most unmarked way of addressing an interlocutor is to use the second-person singular form (ie, an informal or T-form); in requests the overt pronoun is not typically used (Lappalainen 2006b; Seppänen 1989; VISK $2008 \S 100)$. An example is supplied in (1).

\section{(1) Voisitko tuoda vettä? \\ 'Could you (informal) bring some water?'}

The second person singular is marked on the verb, as illustrated with underlining. The so-called "polite" address is the second person plural form, also with no subject pronoun.

The Finnish form meaning "to have" is always marked for person, as shown in (2).

(2) Huomasin, että teillä on uusi aikataulu.

'I noticed that you (formal/plural) have a new timetable.'

The Finnish possessive form also marks for person, thereby showing the $\mathrm{T} / \mathrm{V}$ distinction in the second person. The possessive forms of Finnish are presented in (3a-c). ${ }^{2}$

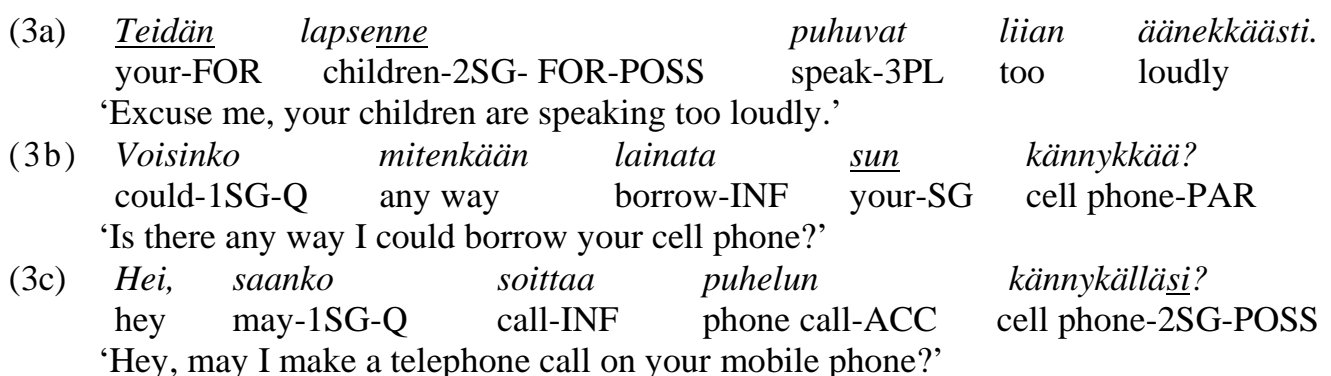

As shown in (3a-c), possessive morphology in Finnish occurs in three different forms. The prescriptive (i.e., dictionary form) is a pronoun plus a suffix that is marked for person: sinun siskosi 'your sister,' which is the form shown in (3a). However, in spoken language the double-marked possessive form tends to get reduced, especially for first and second person (Paunonen 1995), so that the possessive form consists of a pronoun only: sinun sisko 'your sister,' and especially of a shortened version of this form: sun sisko - as shown in (3b). Neindorf (2005) reports, however, that double marking of possessive forms is being reduced in favor of the suffix-only form, as is (3c). The excess use of pronouns has been advised against in earlier Finnish grammars and normative manuals (Paunonen 1995: 505). Notwithstanding, regardless of the possessive variant used, a possessive construction in Finnish exhibits a T/V distinction, and any example in the data that follows the patterns shown in (3a-c) counts as a token of either a T- or V-variant.

\footnotetext{
${ }^{2}$ A glossing guide is supplied in Appendix A.
} 
According to Seppänen (1989), the informal variant (T-variant) was historically the basic form in Finnish, with the formal variant (V-variant) and also the use of a third person perspective coming into use later, concurrent with the use of these forms in other parts of Europe (Seppänen 1989: 197). In the 1960s, it is thought to have became more common to address an interlocutor in the second-person singular, marking an end to a period, starting from the end of the $19^{\text {th }}$ century, during which it became common to address a person with the formal te 'you' (Yli-Vakkuri 2005: 190).

The use of passives (as discussed in the previous subsection), as well as other constructions, enables a speaker to avoid using any markings for second person (VISK 2008; Yli-Vakkuri 2005). In their analysis of terms of address in dialogues in debates between candidates during the Finnish presidential elections, for example, Nuolijärvi and Tiitula (2001) found that direct terms of address were rarely used, although they found differences in personal styles. One presidential candidate (the current Finnish president, Tarja Halonen), employed the formal second person terms of address as a way of creating distance, whereas the other candidate was found to avoid direct terms of address altogether.

In Brown and Gilman's (1960) influential paper on terms of address, pronouns are the focus of discussion. From their point of view, the formal (V-variant) is aligned with non-equal power, while the non-formal (T-variant) is aligned with equal power and solidarity. Clearly, in Finnish the T/V distinction applies to more than just pronouns, also including possessive forms and verbal markings. For this study, the speech act data was coded according to the presence of any of the $\mathrm{T} / \mathrm{V}$ forms that are demonstrated in examples (1-3). Hereafter these forms will be called by the terms "V-variant" for the formal and "T-variant" for the informal.

Previous work on $\mathrm{T} / \mathrm{V}$ forms in Finnish has tended to make use of naturalistic conversation data, using conversation analysis as the methodology. For example, in her ongoing work, Lappalainen (2003, 2006 a and b, 2008) looks at numerous conversations from different institutional and casual settings. In her work based on conversations between government workers and customers at offices of the Social Insurance Institution of Finland, Lappalainen (ibid) notes a trend for employees aged approximately 40 and under to reciprocate the T-variant in Finnish with customers, almost without exception. Retired people over the age of approximately sixty years tend to be called by the Vvariant.

Clyne et al (2006) make a comparative study of $\mathrm{T} / \mathrm{V}$ forms in German and Swedish, including the Swedish spoken in Vaasa, Finland (Finnish and Swedish are both national languages of Finland; some 5.5 percent of the Finnish population has Finland Swedish as a mother tongue). Their data, which comes from focus group conversations among approximately 16 native speakers in several locations, is both metalinguistic (people talk about the $\mathrm{T} / \mathrm{V}$ distinction), as well as empirical, coming from the conversations themselves. They report that the T-variant is the unmarked pronoun of address used in the Swedish spoken in Finland. However, the Swedish-speaking respondents living in Finland reported that they use the V-variant in a broad range of situations. The main findings of this study were that age/generation is the most important

\footnotetext{
${ }^{3}$ While a study of which grammatical sites (pronouns, verbs, or possessive forms) tend to show the $\mathrm{T} / \mathrm{V}$ distinction would be interesting in its own right, an analysis of this distinction was outside the parameters of the current study.
} 
factor affecting choice of pronoun, and that distance is also important; the combination of age and distance was the most likely combination to elicit $n i$ 'you' (V-form).

To my knowledge, there are no published studies that treat perspective or the T/V distinction in Finnish using elicited request speech acts as a quantitative data source. Perhaps the most applicable work (for comparative purposes) is that of Lappalainen (2003, 2006 a and b, 2008), who, although she uses naturally-occurring conversation data, looks at requests, quantifies her data and presents generalized results according to such factors as age of speakers and interlocutors, setting, etc. Lappalainen tends to present results according to preferred patterns of use based on several hours of conversation, then goes on to discuss in a qualitative fashion conversations or utterances that deviate from the norm. For example, in her 2008 paper on routinized requests made in Finnish insurance offices, she analyzed nearly 22 hours of videotaped conversations between workers and customers. She viewed the requests made of customers from 20 different insurance office workers. In this setting, she found that the most typical request was to ask in the second person singular in a T-from, using an interrogative verb:

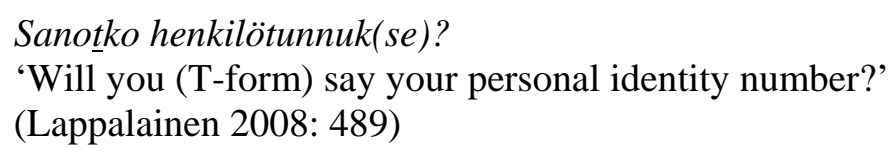

Lappalainen concludes that a T-form is the basic variant to address customers under approximately 40 years of age, while the V-form, if it is used at all, is reserved for people who are clearly over the age of 60 . There was evidence of variation both in the request perspective and in the use of T/V forms to address people between the ages of 40 and 60 . She also noted evidence of regional variation and according to the identification of the customer (with evidence of status being an influence; for example, if a customer was a doctor).

In summary, previous studies of forms of address and requesting behavior in Finnish show that age of the interlocutor, social distance, as well as region, are factors that affect request perspective and also the use of $\mathrm{T} / \mathrm{V}$ forms. This paper seeks to view request perspective from the point of view of sociopragmatic factors that, aside from social distance, have not been studied before, and, in doing so, to note:

1) How is the selection of perspective and forms of address motivated by the external factors?

2) Do the findings support previous studies, which conclude that social distance is the most important sociopragmatic factor?

3) Do the sociopragmatic factors offer a helpful way of accounting for the distribution of pragmatic variants?

It is expected that speakers are more willing to use a second person perspective and a Tform of address in relatively routine requests (ie, low rate of imposition) made of social intimates or of people who are of equal or lesser social standing (ie, equal rate of social power or less social power). A first or third person perspective is most likely to be used when the rate of imposition is high, when the social status is unequal, or when the interlocutor is someone who is unknown to the speaker. A first person perspective is most likely when an object is being requested. In keeping with the literature on Finnish forms of 
address and requests, the question of social distance is expected to have the most influence on the forms that are tested.

\section{Data and methodology}

The data for the study were elicited through scripted, face-to-face interviews with 68 speakers of Finnish who all lived in the greater Helsinki area. In total, there were 509 request utterances that were transcribed from audio recordings, then coded and analyzed. The elicitation tool used for this study was a modified version of the Discourse Completion Task (DCT), first developed by Blum-Kulka (1982) for her study of speech acts.

\subsection{Speech acts and requests}

Speech acts have been a central focus of investigation for many years now in quantitative pragmatics. This study focuses on request speech acts. Requests are often analyzed in speech act studies due to their relatively commonplace nature, because they are inherently face-threatening, and because they tend to exhibit culturally and linguistically specific properties of socially-appropriate usage (Churchill 1999). Requests were thus deemed an appropriate focus for this study, also because requests were considered an everyday speech act that Finnish people could easily relate (compared to, for example, compliments). In addition, requests are a speech act that exhibit variation in terms of perspective, terms of address, as well as other politeness forms, thereby suiting the features of investigation in the study.

\subsection{The questionnaire}

This study makes use of a questionnaire with seven scenario prompts to elicit request speech acts. While it is well documented that naturally occurring data are in many ways preferable to elicited speech data, naturally occurring data present certain challenges in quantitative studies due to the non-uniform nature of the data (for example, there is little control over external variables), as well as the practical fact that many pragmatic/linguistic forms cannot be observed in adequate quantity in naturally-occurring situations.

In quantitative studies of pragmatics, a widely used resource for addressing these challenges has been the Discourse Completion Task. DCTs enable researchers to gather large amounts of data in a set amount of time, and, further, the data is readily analyzable due to the fact that external variables have been normalized.

Although DCTs have taken a strong foothold in speech act studies, their limitations have been quite well documented. For example, some researchers have compared spoken data to written DCT data and found that the DCT is not as robust (Hartford and BardoviHarlig 1992). Others have pointed out that naturally-occurring speech acts are embedded in conversations, and that DCT prompts therefore do not contain the turns or structure of "real" speech acts (Harris 2003). In addition, through the construal of make-believe scenarios, respondents are faced with the challenge of imaging themselves in situations that may not relate to their real life (for example, a student being asked to imagine herself 
as a boss at a company), thereby affecting the authenticity of the response; participants can only comment on what they think they would say (see Byon 2006).

The DCT was considered the best means of gaining data for this study for several reasons. First, the data needed to be controlled in order to gain representative numbers that would make statistical analysis feasible. Second, because I was working under time constraints in a non-native speech community, other methods, such as participant observation or role playing, were deemed too time-consuming and invasive. Third, some of the issues associated with the "lean" results of DCTs were mediated by sitting down face-to-face with the participants, and asking them to answer the DCT prompts orally. This set-up resulted in many elaborations on the request prompts, as well as rich metalinguistic data. The face-to-face set-up also made it possible for participants to "opt out" of giving an answer to any DCT scenario that they thought unrealistic or inappropriate. The face-to-face set-up had the unanticipated outcome that participants offered more than one response to each prompt; several participants paused, reconsidered, and then offered a second or even a third response to each scenario.

The scenarios used to elicit requests were designed with the Helsinki speech community in mind. The questions were tested in advance with a focus group and were duly modified before they were used to elicit the data reported in this study. The datagathering portion of the study took place during 2001. During each interview, the participant was asked to comment if any of the prompts felt unnatural, and to explain why. To avoid influencing the responses, words such as "request" or "politeness" were not used during the interviews.

The scenarios used in the study depict everyday situations that vary in the level of power, distance, rate of imposition (Brown and Levinson 1987), and requestive goal (Varghese and Billmyer 1996). These variables are considered to have an effect on pragmatic features of speech, such as ways of marking directness, politeness, and mitigation (Brown and Levinson 1989; Blum Kulka et al 1989). The power variable has a trinary value, where the speaker has either higher, lower, or equal status to the hearer. The distance variable is binary; either the speaker is familiar with the hearer, or not. The rate of imposition is also a binary value; the request is a "big deal," or it is not. The requestive goal of the utterance refers to the outcome the speaker is trying to achieve through the request; in this study, the outcome is defined either as an object or as an action.

A summary of the property of the requests tested in the study is presented in Table 1.

Table 1. Social variables present in scenarios

\begin{tabular}{lllll}
\hline Situation & Power & Distance & Imposition & Goal \\
\hline 1. Boss & $\mathrm{S}>\mathrm{H}$ (+power) & Familiar (-distance) & low (-) imposition & action \\
2. Lunch & $\mathrm{S}<\mathrm{H}$ (-power) & Unfamiliar (+distance) & high (+) imposition & action \\
3. Bus & $\mathrm{S}=\mathrm{H}$ (=power) & Unfamiliar (+distance) & low (-) imposition & object/action \\
4. Salt & $\mathrm{S}=\mathrm{H}$ (=power) & Familiar (-distance) & low (-) imposition & object \\
5. Phone & $\mathrm{S}=\mathrm{H}$ (=power) & Unfamiliar (+distance) & high (+) imposition & object \\
6. Movie & $\mathrm{S}=\mathrm{H}$ (=power) & Unfamiliar (+distance) & high (+) imposition & action \\
7. Water & $\mathrm{S}>\mathrm{H}$ (+power) & Unfamiliar (+distance) & low (-) imposition & object/action \\
\hline
\end{tabular}

Note that for scenarios 3) Bus and 7) Water, the requestive goal is split between object and action. This is because some of the speakers who responded to the request prompts interpreted these situations as requests for an object, e.g., a glass of water, whereas others requested action, e.g., “Can you tell me when the next bus is coming?” 
Clearly, the seven prompts (which are shown in their entirety in Section 4) do not exhaust all possible combinations of the social variables. This is because of the limitations of creating authentic enough scenarios, and also because the cognitive demands of the questionnaire are quite great - further questions could cause mental fatigue for the participants, and therefore diminish the quality of their responses.

\subsection{Politeness Theory}

In essence, this is a study of politeness, based on the premise that request perspective and forms of address index social norms in Finnish. Like many studies of linguistic politeness, this one draws on the Politeness Theory presented by Brown and Levinson (1978/1987).

Brown and Levinson's theory, which adopts Goffman's (1967) concept of “face," claims that in a "face-threatening" interaction a speaker will try to appeal to a hearer's "negative face," meaning the possibility to retain autonomous and unencumbered, or the hearer's "positive face," meaning the possibility to cooperate and build camaraderie. During a face-threatening act (such as making a request), using either "positive politeness" strategies or "negative politeness" strategies helps a speaker to attempt to preserve or achieve either positive or negative face. For example, when making a request, a third person construction such as Would it be possible to shut the window? is a negative politeness strategy that relinquishes both the speaker and the hearer of agency, and thereby appeals to their negative face.

The power, distance, and rate of imposition variables were defined by Brown and Levinson as three social variables present in any communicative situation that combine in culturally-specific measures to affect the politeness used in a communicative act. For example, a high rate of imposition could prompt speakers to use positive politeness forms, trying to relate to the hearer, whereas a conventionalized is an appeal to negative face and negative politeness forms. For Brown and Levinson, the "weightiness" of a speech act performance can be measured through the formula Distance + Power + Degree of Imposition $=$ Weightiness.

While Brown and Levinson's Politeness Theory remains the most cited in the literature, it has been criticized on several fronts. Several researchers have posited differing accounts of linguistic politeness, including Lakoff (1973, 1975), Leech (1983), and Watts, Ide, and Ehlich (eds. 1992). However, like Brown and Levinson's theory, each of these accounts has been criticized for supposed weaknesses ranging from a Western ethnocentric bias to being overly simplistic.

Eelen's (2001) account addresses some of the more common criticisms of existing politeness theories. He argues for distinguishing two types of politeness: politeness1 is the everyday sense type of politeness, and politeness 2 is the scientific idea of politeness. The two types of politeness fit together, politeness2 serving as the theoretical underpinnings of the social phenomenon of politeness, i.e., politeness1. Politeness1 is what lay people think of when they conceptualize politeness; this type of politeness, then, lies on the "polite" end of the polite-impolite continuum. Politeness2, on the other hand, covers the entire continuum.

A chief criticism of existing politeness theories is that they appear to posit polite and impolite behavior, two opposing extremes, as accounting for the complexities of social interaction. Like Eelen, other researchers have pointed out that the term politeness itself implies a polarity, so that a given society may be inaccurately perceived as being 
either "polite" or "not polite" (for example, Blum-Kulka, 1990; Meier 1995a and b). These researchers point out that all societies have culturally specific methods of expressing "politeness," and that even within a given society, there are a variety of ways to express "polite" behavior.

I chose to make use of Brown and Levinson's Politeness Theory for several reasons. First, although the binary values ("positive" and "negative") have been criticized as being overly simplistic, this clear division nonetheless offers the researcher (and readers) a relatively straightforward way of viewing politeness data. However, I shall appeal to these divisions only for the sake of description; assigning negative and positive politeness strategies is not a focal point of the study.

Second, my previous work on variation of pragmatic features in requests (Peterson 2004) illustrated that the sociopragmatic variables of power, distance, and rate of imposition showed promise in accounting for pragmatic variation. A likelihood ratio ("goodness of fit") test showed that the P, D, and R variables were better at accounting for the distribution of pragmatic variables than social factors such as sex, age, and social class which are more commonly used in variationist studies. The current study thus serves the purpose of further testing the suitability of the $\mathrm{P}, \mathrm{D}$ and $\mathrm{R}$ variables in accounting for the distribution of the pragmatic variables of request perspective and forms of address. The basic premise is that pragmatic variants are indexical with sociopragmatic factors.

\subsection{Study participants}

The linguistic data came from 68 Finnish speakers living in the Helsinki area. These participants were invited to the interviews through the "network" approach (Milroy 1980), yielding a non-representative, non-random sample. Speakers tended to be somewhat younger than the average Finnish population, with the majority of speakers (30 percent) aged 26-30. Nearly 50 percent of the participants were under the age of 30 . There were 21 men and 47 women. The participants were biased toward the professional middle class and students; at the time of the study 15 participants were attending university, and two-thirds had attended at least some university (compared to half of the overall Finnish population, Statistics Finland 2010). Each participant was interviewed personally by the researcher, with each interview lasting approximately 30-60 minutes. All interviews were tape recorded in their entirety.

\subsection{Variation theory and pragmatic variables}

Among the wealth of variationist studies that have been conducted in recent decades, there are still relatively few that view pragmatic data, and the difficulties in applying a variationist framework to syntactic and pragmatic data is well documented (see Lavandera 1978; Sankoff 1974). ${ }^{4}$ At the same time, variationist studies have tended to use social and grammatical categories as independent variables rather than sociopragmatic categories. This study is thus exploratory first in that it considers pragmatic data and second in that it

${ }^{4}$ Paolillo (2002) offers a thorough overview of the variables - phonological, morphological, syntactic, and other - that have been the focus of variationist studies. 
attempts to account for variation in the pragmatic data through sociopragmatic categories rather than social categories.

Dines (1980) offers the following helpful criteria for observing variables at the level of discourse. First, the variants must be considered to have a common function in discourse. Second, the variants must be predictably distributed according to linguistic and social conditions. Finally, there must be a degree of saliency associated with the variants within the speech community.

Following this reasoning, the Finnish $\mathrm{T} / \mathrm{V}$ forms are treated as variants of a single variable: Ways of addressing someone in the second person. The dependent and independent variables are viewed in detail in the next subsection.

\subsubsection{Variationist analysis}

This study makes use of Varbrul, a software system developed for use by researchers of linguistic variation to account for the distribution of linguistic features according to variable rules. Originally developed as a program for determining probabilistic weights (Cedergren \& Sankoff 1974), more recent versions perform logistic regressions for categorical data to help reveal relationships between linguistic and other factors. These versions, like the original, still express outcomes as probabilistic weights (Paolillo 2002). The program outputs a range of weights, typical values, and input probabilities. The Varbrul version used for this study is GoldVarb X (Sankoff et al. 2005).

A Varbrul program analyzes a dependent linguistic feature, a variable, which is comprised of two or more variants that are distributed according to independent factors. In this study, the $\mathrm{T} / \mathrm{V}$ forms of the second-person singular are treated as variants of a single variable, made up of the a T-variant, the $\mathrm{V}$-variant, or the lack thereof, which, for the sake of brevity (and for lack of a better term), I refer to as the 0 -variant. The independent factors are the $\mathrm{P}$-variable, comprising three variants $(-\mathrm{P},+\mathrm{P},=\mathrm{P})$, the $\mathrm{D}$-variable, comprising two variants $(-D,+D)$, the R-variable, comprising two variants $(+R,-R)$, and the request goal variable (Action, Object, Action/Object). A fifth independent variable, the request perspective (first person, second person, third person), is also included, simply to complement the findings from the study as a whole.

While social features such as age and sex serve generally serve as the independent variables for investigations of phonological or morphological variation, the basic premise here is that pragmatic variation is best accounted for through sociopragmatic independent variables. The study is thus investigative in that it furthers a methodological question raised earlier in my own work, having to do with the adaptability of pragmatic concepts relating to "face" to studies of linguistic variation.

\section{Linguistic forms of perspective}

As was pointed out in the Introduction, there is a clear link between the perspective of a request and the use of $\mathrm{T} / \mathrm{V}$ forms, with the $\mathrm{T} / \mathrm{V}$ form often having a dependent relationship on the perspective (if the perspective is in the second person). For the purposes of this paper, the request perspective is determined according to guidelines set in previous speech act studies (see, e.g., Blum-Kulka et al. 1989): The main verb in the main request, or the 
"head act" of a request utterance, determines the perspective. For example, in the following request utterance, the head act is set apart with underlining:

Voisitko ottaa mun soittopyynnöt? Menen kokoukseen.

'Could you (T-form) take my phone messages? I'm going to a meeting.'

[M26]

Nearly every request utterance gained through the data collection for this study contained a main verb with a first, second, or third (i.e., embedded or general) person perspective, as in example (5). The exceptions included addressing a plural interlocutor (as was often the case for Situation 6: Movie, see below), or when a request did not contain a verb (as was sometimes the case for Situation 4: Salt, and Situation 6: Movie; see below). There were no passive constructions in any of the head acts in the data.

Even though $\mathrm{T} / \mathrm{V}$ forms are not inherent to perspectives other than the second person, there is still the possibility to use T/V forms when a main request is made from a first person or third person perspective. For example, a speaker who wishes to borrow an object from an addressee will likely use a second person possessive form, which by definition contains a $\mathrm{T} / \mathrm{V}$ distinction.

There were several other usages in the request utterances that were marked with $\mathrm{T} / \mathrm{V}$ forms, each of which counted as a token of either a T- or V-form, even if the head act contained a verb inflected in the first or third person. For example, several speakers would foreground a head act with something like:

Onko sinulla minulle tänään erityisiä tehtäviä, tai voinko lähteä aikaisemmin?

'Do you (T-form) have anything special for me to do today, or can I leave early?' [F25]

The speaker makes a bid for cooperation, followed by a head act inflected in the first person singular. This example would count as one token of a T-form, as indicated with underlining.

As discussed in the Introduction, there is variation in Finnish as to whether a verb and a subject pronoun are both present, or, if a subject pronoun is used, if it is in the full, prescriptive form, or in a truncated form. The pronoun forms have been shown to exhibit variation due to domain and level of formality. This study focuses on requests and has a goal of viewing which sociopragmatic factors seem to affect the use of a $\mathrm{T}$ - or a V-variant, and no finer level of analysis is considered. Thus, for example, any manifestation of the Tform, whether there is an overt pronoun or not, or whether the pronoun or possessive form is truncated or not, simply counts as one token of a T-variant.

The analysis is conducted in two parts. First, a basic count per scenario of the perspective of the main verb in each request "head act" is presented, along with information pertaining to $\mathrm{T} / \mathrm{V}$ markings. Sample utterances that best typify preferred forms of use are supplied. The goal of this portion of the analysis is to indicate the request perspective that seems to be favored for use in each of the given situations.

The second part of the analysis makes use of the variationist analysis tool GoldVarb $\mathrm{X}$. The goal of this analysis is to demonstrate which of the sociopragmatic factors seem to most favor the use of a T/V form, as well as to address the methodological question of the suitability of Varbrul to use sociopragmatic parameters to observe pragmatic data. 


\section{Data analysis of Finnish requests}

A summary of the distribution of perspective and forms of address from the Finnish requests is presented in Table 2.

Table 2: Distribution of perspective and T/V forms per scenario

\begin{tabular}{|c|c|c|c|c|c|c|c|c|}
\hline & Boss & Lunch & Bus & Salt & Phone & Movie & Water & $\begin{array}{l}\text { \% } \\
\text { of total }\end{array}$ \\
\hline perspective & (f) $\%$ & (f) $\%$ & (f) & (f) $\%$ & (f) $\%$ & (f) $\%$ & (f) $\%$ & \\
\hline $1^{\text {st }}$ person & (1) 1 & (40) 54 & (19) 26 & (9) 8 & (32) 59 & (3) 4 & (61) 82 & 32 \\
\hline $2^{\text {nd }}$ person & (74) 99 & (0) 0 & (42) 57 & (68) 92 & (8) 15 & (65) 88 & (13) 17 & 53 \\
\hline $3^{\text {rd }}$ person & (0) 0 & (34) 46 & (13) 17 & (0) 0 & (14) 26 & (6) 8 & (1) 1 & 13 \\
\hline & & & & & & & & $100 \%$ \\
\hline$T / V$ forms & & & & & & & & \\
\hline $\mathrm{T}$-forms & (74) 99 & (3) 4 & (30) 40 & (65) 92 & (46) 85 & (6) 8 & (12) 16 & 50 \\
\hline V-forms & (1) 1 & (0) 0 & (24) 33 & (0) 0 & (6) 11 & (6) 8 & (1) 1 & 10 \\
\hline none/plural & (0) 0 & (71) 96 & (20) 27 & (9) 8 & (2) 4 & (62) 84 & (62) 83 & 40 \\
\hline & & & & & & & & $100 \%$ \\
\hline (\# / tokens) & 75 & 74 & 74 & 74 & 54 & 74 & 75 & (500) \\
\hline
\end{tabular}

Out of a total of 509 possible request utterances gained from the interviews, 500 contained the relevant variables for this study ${ }^{5}$. As illustrated in Table 2, a second person perspective was the preferred form in the requests that were elicited for the study, accounting for the majority (53 percent) of the request head acts. T-forms were the most common form of address. Exactly half of the request utterances were marked with a T-form. V-forms were clearly not preferred, occurring in only 10 percent of the 500 request utterances.

\subsection{Summary of features per scenario}

\section{Situation 1: Boss (+P, -D, $-\mathrm{R}, \mathrm{A})^{6}$}

You work at a telecommunications company. You ask your assistant to take your phone messages while you are in a business meeting. Your assistant has worked in your department for five years. You say:

In this situation, the speaker is in a position of power, but is asking a request of someone who is familiar. According to Brown and Levinson's Politeness Theory, we would expect that this situation, in a relatively equilateral society such as Finland, would prompt the use of a positive politeness strategy, which in fact seemed to be the case.

The preference was for a second person perspective request, which meant that the vast majority of the responses to this prompt, 99 percent of them, were marked with T/V forms. A typical response to this scenario is shown in example (7).

${ }^{5}$ Requests that did not count as tokens contained no verb and therefore no perspective. These included, for example, commands such as Suolaa! 'Salt!' and Shhhhh!

${ }^{6}$ The original Finnish version of the prompts is presented in Appendix B. 
Jos joku soittaa mulle, voisitko ottaa soittopyynnön? Menen kokoukseen.

'If someone calls me, could you (T-form) take a message? I am going to a meeting.

As shown in the example, most speakers make a request from a second person perspective, using the Finnish modal voida 'can,' and also made some sort of explanation, such as, "I am going to a meeting."

The only exception to this routine came from a 24-year-old man, who said simply Menen kokoukseen 'I'm going to a meeting,' with the explanation that someone who had worked in the company for five years should know what to do in such a situation.

There was only one participant, a 29-year-old woman, who used a V-form to make this request. When asked later in the interview about her response, she characterized her own speech as "excessively formal."

\section{Situation 2: Lunch (-P, + D, +R, A)}

You are a secretary, and you have worked at the company for three weeks. Today you want to meet a friend for lunch, so you ask your supervisor if you can leave early. You say:

The setting for this situation is more or less the same as the previous, but now the speaker is in a position of relative powerlessness, with the added difficulty of asking permission of a supervisor who is still quite unfamiliar, which counted as a high imposition request. ${ }^{7}$ In this situation, Brown and Levinson's model would predict the use of negative politeness strategies, which would point towards the use of a first or third person perspective. The results support this assertion.

All of the responses to this prompt were made from a first or third person perspective. The majority of the requests, 54 percent, were made from a first person perspective, as in (8).

(8) Haluaisin lähteä tänään vähän aikaisemmin.

'I would like to leave a little earlier today.' [F42]

The remaining 46 percent of the requests were made from a third person (embedded) perspective, Onko/olisiko mahdollista ...? 'Is it/would it be possible ...?'

Even though there were no requests from this scenario in a second person perspective, a few speakers addressed the scripted supervisor in some kind of bid for cooperation, as in example (9):

Hei, voinks mä kysyä sulta yhtä asiaa?

'Hey, can I ask you (T-variant) something?' [F35]

7 It should be noted that several of the participants in the study found this scenario to be problematic, claiming that in Finnish office culture, one would not need to ask permission to leave work. 


\section{Situation 3: Bus (=P, +D, -R, O)}

You are waiting for a bus near your apartment. You have an old timetable, and you don't know when your bus will arrive. A woman who lives in your building is also at the bus stop, but you don't know her. She has a new timetable. You say:

In Finnish society, the power status between the speaker and an unknown interlocutor is best described as equal (although it could be argued that the addressee is in a position of power because she has something the speaker wants; see Locher 2004).

This scenario resulted in less congruent responses than the previous two. There were more examples of a second-perspective request than first or third person perspectives, meaning that the most common request type was something similar to example (10).

\section{Anteeksi, mutta tiedätkö milloin tulee seuraava bussi?}

'Excuse me, but do you (T-form) know when the next bus is coming? [F30]

Even when a first or third person perspective was used, speakers often used a possessive $\mathrm{T} / \mathrm{V}$ form, as in (11).

$$
\begin{aligned}
& \text { Saisinko lainata bussiaikatauluasi? } \\
& \text { 'Could I borrow your (T-form) bus timetable?' [F24] }
\end{aligned}
$$

There were some speakers, however, who used a neutral form even when asking for the timetable, as in example (12).

$$
\begin{aligned}
& \text { Hei, voisinko katsoa aikataulua? Kiitos. } \\
& \text { 'Hey, could I look at the timetable? Thank you.' [F30a] }
\end{aligned}
$$

One speaker began his request utterance for the bus stop scenario by addressing the woman with a verb marked for a V-form, then switched to a third person perspective:

$$
\begin{aligned}
& \text { Anteeks, mutta voitteks sanoa... Anteeks, milloinkohan seuraava bussi tulee? } \\
& \text { 'Excuse, but could you (V-form) say ... Excuse me, when is it that the next bus is } \\
& \text { coming?' } \\
& \text { [M44] }
\end{aligned}
$$

This was the scenario to prompt the most frequent use of V-forms (in 33 percent of the total requests for this scenario), which could have to do with the sociopragmatic factors, but also with the wording on the questionnaire. Many of the participants in the study pointed out that the use of the word nainen 'woman' made them imagine someone older, which could influence them to use a V-variant as a form of address.

\section{Situation 4: Salt (=P, -D, -R, O)}

You are cooking dinner at home, and your (close relation) is in the kitchen. You need salt, and your hands are oily. You say:

This situation contains the same sociopragmatic variables as the previous, save for the crucial distinction that the interlocutor is someone who is an intimate. The lack of social 
distance, combined with the low rate of imposition, resulted in uniform responses. A second person perspective was used in 92 percent of the responses to this scenario, and all of these made use of a T-form, as shown in (14).

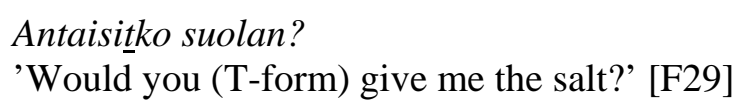

This scenario, along with Scenario 1 "Boss" were the only two that were scripted as addressing a social intimate, and more than 90 percent of the responses to these prompts contain a second person perspective in a T-form. This result mirrors those of previous studies on Finnish T/V forms, which have found social distance to be an important factor in determining terms of address.

\section{Situation 5: Phone (=P, +D, +R, O)}

You are on your way downtown on the bus, and your mobile phone's battery is dead. You need to phone your friend to decide where you will meet for coffee. The person sitting next to you, who is about your same age, has a mobile phone. You say:

The sociopragmatic parameters of this scenario mirror those of Situation 3, but speakers are now faced with the added difficulty of asking to use a mobile phone. Note that this is the only scenario to specify that the interlocutor is "about your same age." This information was supplied in an attempt to raise speakers' comfort level in making the request. Even so, this was considered such a high imposition request that 16 of the 68 speakers "opted out," saying that they would never make such a request, especially in what they considered a non-emergency situation.

Of the 54 total responses to this scenario, 57 percent had a head act with a first person perspective. As with the bus stop scenario, using a first person perspective did not eliminate the need to mark the utterance with $\mathrm{T} / \mathrm{V}$ forms, as it was still necessary to ask for the interlocutor's telephone, which tended to require a second-person possessive for the object noun phrase:

Voinko käyttää puhelintasi? Voin maksaa puhelusta.

'Can I use your (T-form) phone? I can pay for the call.' [F30C]

Unlike the bus stop scenario, which also made a request of a stranger, the cell phone scenario specified that the interlocutor was about the same age as the speaker. This information seemed sufficient for the vast majority of the responses (85\%) to contain a Tform, apparently overriding the fact that this scenario was considered more high imposition than Scenario 3. The six people who did use a V-variant in response to this scenario said they did so because the request was "big" and because the person was a stranger.

\section{Situation 6: Movie (=P, +D, $+\mathrm{R}, \mathrm{A})$}

You are in the audience at a movie. The two little girls in front of you are talking, and you can't hear the movie. You decide to say something to their mother. You say: 
This situation is similar in set-up to the previous, except that the speaker is requesting action on the part of the interlocutor rather than an object. Participants frequently commented on the discomfort associated with making such a face-threatening request. The setting of the movie theater further complicated the matter, as they felt inclined to strive for positive politeness strategies, but lengthy utterances would be inappropriate in such a setting. A third complication with this scenario is that it specifies the mother as the interlocutor; several speakers said they would address the two girls directly, depending on such factors as age, the level of the noise, etc.

The most common strategy, accounting for 40 percent of the tokens, was to make a request in the second person, addressing the two girls in the plural, as in (16).

Voisitteko puhua vähän hiljempaa?

'Could you (plural) speak a little quieter?'

Of the tokens which addressed the mother in the second person, half contained a V-form and half a T-form. One speaker started to address the mother in a V-form and then changed her mind half way through her utterance:

(17) Oletteko näiden tyttöjen äiti, ja voisitteko pyytää ... tai voisitko, it depends, pyytää heitä olemaan hiljaa?

Are you (V-form) these girls' mother, and could you (V-form) ask ... or could you (T-form), it depends, ask them to be quiet?

The speaker began her request in a manner which made use of formal V-forms of address, then paused, reconsidered, explaining in English it depends, then continued her request with a T-form. This example is a good illustration of the complexity of choosing a form of address, and how the DCT prompts could lack relevant information in helping a speaker choose one form over another.

\section{Situation 7: Water $(+P,+D,-R, 0)$}

You are eating at a restaurant. You are already eating your meal, and then you decide you would like to have some water. The waiter comes to the table, and then you say:

Of all the scenarios, this was arguably the one to elicit the most formulaic requests. As the final request prompt, this situation prompted several comments of relief from the participants, who claimed this request was "easy."

The majority of the requests (82 percent) were made from a first person perspective, using either using the Finnish modal verb saada or voida, without marking the utterance with T/V forms:

Anteeksi, saisinko vielä vettä?

'Excuse me, could I still get some water?' 


\subsection{Distribution of $T / V$ forms according to GoldVarb}

The goal of the Varbrul analysis is to complement the more impressionistic scenario count that has just been presented. The Varbrul results are presented in three tables; there were three separate analyses using GoldVarb X, one for each of the dependent variants: $T$ variant, V-variant, 0-variant. ${ }^{8}$

\section{Table 3 Factors influencing T-variant}

input .594 significance .078

\begin{tabular}{|c|c|c|c|}
\hline Power & $\underline{\mathrm{N}}$ & $\underline{\%}$ & $\underline{\mathrm{P}}$ \\
\hline$+\mathrm{P}$ & $85 / 148$ & 57 & .72 \\
\hline$-\mathrm{P}$ & 4/73 & 5 & .20 \\
\hline$=\mathrm{P}$ & $164 / 268$ & 61 & .47 \\
\hline \multicolumn{4}{|l|}{ Goal } \\
\hline Action & 99/196 & 50 & .41 \\
\hline Object & $113 / 145$ & 78 & .88 \\
\hline Action/Object & $41 / 148$ & 28 & .19 \\
\hline \multicolumn{4}{|l|}{ Perspective } \\
\hline$\overline{1 . p e r s o n}$ & 35/153 & 21 & .16 \\
\hline 2.person & $203 / 238$ & 85 & .81 \\
\hline 3.person & $15 / 75$ & 20 & .23 \\
\hline
\end{tabular}

In Table 3, the figures under the "N" indicate the total number of times the dependent variant occurred in the same token as the independent variant. The next column of figures represents the percentage rate at which the dependent variant occurred in the same token with the independent variant. The column of figures underneath the " $P$ " indicates the probability that the dependent variant occurs in the same token with an independent variant. A probability greater than .5 means there is a strong relationship between the two variants.

GoldVarb selected the power factor, the requestive goal, and the perspective as the most important factors that show variability with the T-variant. The distance factor and rate of imposition were not selected. The factors that were selected as influencing the use of the T-variant all point toward the use of positive politeness strategies. For example, the T-variant was favored for use when a speaker was in a position of relative power and when the desired requestive outcome was an object. As would be expected, a T-variant is favored to occur when a request is made from a second person perspective.

Previous studies on the use of T/V forms in Finnish have found the social distance between speakers to be an important factor, which raises the question as to why it was not selected as an important parameter by Varbrul. One explanation is that Varbrul is a test of variation, and where no variation is present, Varbrul does not select a given factor group (Tagliamonte 2006: 152). In the case of the distance factor, out of 149 request tokens that were addressed to a familiar interlocutor, 140 of them (94 percent) contained a T-variant. Thus, using a T-form for a familiar addressee is categorical.

\footnotetext{
${ }^{8}$ Goldvarb X does not allow multivariate analyses.
} 
Table 4 Factors influencing V-variant

input .034 significance .013

$\begin{array}{llll}\frac{\text { Power }}{+\mathrm{P}} & \underline{\mathrm{N}} & \frac{\%}{\mathrm{P}} & \underline{.08} \\ =\mathrm{P} & 1 / 148 & 0 & .79 \\ \begin{array}{l}\text { Distance } \\ \text { Familiar }\end{array} & 48 / 268 & 18 & \\ \text { Not familiar } & 1 / 149 & 0 & .17 \\ \text { Goal } & 48 / 340 & 14 & .70 \\ \text { Action } & & & \\ \text { Object } & 17 / 196 & 8 & .63 \\ \text { Action/Object } & 6 / 145 & 4 & .26 \\ \begin{array}{l}\text { Perspective } \\ \text { 1.person }\end{array} & 26 / 148 & 17 & .64 \\ \text { 2.person } & 10 / 153 & 6 & .44 \\ \text { 3.person } & 34 / 238 & 14 & .57 \\ \text { Rate of imposition (R variable) not selected } & .27\end{array}$

The low input, number of tokens and percentages mirror the findings presented previously: The V-variant was not favored for use under any circumstances. Note that there were no instances of use of a V-form when an addressee was in a position of social power (this was a Varbrul "knock-out"). As mentioned previously, the V-variant is an example of a negative politeness strategy, and, as such, it seems to have been used in situations where such a strategy was deemed necessary. A situation in which the speaker and addressee shared equal social power, were strangers, and in which the stranger was asked for an object seemed the most likely to elicit use of a V-variant. The rate of imposition of the request was not selected as having an influence on the use of a V-variant.

Table 5 Factors influencing 0-variant input .020 significance .003

$\begin{array}{llll}\frac{\text { Power }}{+\mathrm{P}} & \underline{\mathrm{N}} & \frac{\%}{2} & \underline{\mathrm{P}} \\ -\mathrm{P} & 62 / 148 & 42 & .91 \\ =\mathrm{P} & 69 / 73 & 95 & .81 \\ \underline{\text { Imposition }} & 36 / 268 & 13 & .15 \\ \text { High } & & & \\ \text { Low } & 80 / 192 & 42 & .08 \\ \text { Goal } & 87 / 297 & 29 & .83 \\ \text { Action } & & & \\ \text { Object } & 78 / 196 & 40 & .83 \\ \text { Action/Object } & 9 / 145 & 6 & .43 \\ \begin{array}{l}\text { Perspective } \\ \text { 1.person }\end{array} & 80 / 148 & 54 & .14 \\ \text { 2.person } & & & \\ \text { 3.person } & 108 / 153 & 71 & .98 \\ \text { Distance (D variable) not selected } & & \end{array}$


The outcome for this variant is included to illustrate the sociopragmatic factors that tended to be present when speakers did not choose to include $\mathrm{T} / \mathrm{V}$ markings in their request utterances. T/V markings were not favored for use when there was unequal power status, when a request was considered low imposition, or when the desired outcome of a request was an action. The lack of $\mathrm{T} / \mathrm{V}$ markings did not occur when a request was made from a second person perspective.

\section{Discussion, applications for future study}

This paper has made use of request speech act data in Finnish to view how perspective and forms of address vary according to the sociopragmatic factors present in a given situation. The results were first presented according to the scenarios that prompted the requests, then the distribution of $\mathrm{T} / \mathrm{V}$ forms, as determined from a Varbrul analysis, was presented. Previous studies on T/V forms in Finnish have found age of the addressee relative to the speaker, as well as social distance, to be important factors influencing the use of a given $\mathrm{T} / \mathrm{V}$ variant. However, previous studies have not focused on the request speech act, of, if they did, they did not use questionnaire data that elicited a variety of request types. This study attempted to use the sociopragmatic variables presented by Brown and Levinson (1987) as a way of viewing the variability of the T/V forms across situation types, with the notion that sociopragmatic factors are relevant predictors of pragmatic data.

A high level of congruency was found in response to situations that were seen as formulaic or unproblematic in terms of social relations. For example, in Scenario 1 "Boss" and Scenario 4 "Salt," the combination of a low rate of imposition and familiarity resulted in the use of straightforward use of a second-person perspective and a T-form in nearly all of the requests. These two situations showed that using a T-form to address someone familiar is practically categorical. On the other hand, a situation that was highly-face threatening, such as asking special permission from a relatively new supervisor, as in Scenario 2 "Lunch," resulted in no requests made in a second person perspective. Rather, speakers opted for a request that preserved the addressee's negative face, either a first person or third person perspective. Scenarios where the addressee was a stranger, combined with a high rate of imposition, elicited the most variation in terms of perspective. Thus, any congruency in the outcome of request perspective seemed to reflect set social roles and low-imposition requests.

The T/V forms were the focus (the dependent variable) in the Varbrul analysis. The results showed that if a V-variant was used, it was most favored in a situation where power was equal, but where there was social distance between the speaker and addressee. This supports the findings of the results presented per scenario; the V-form was more frequently used in Scenarios 3 "Bus," 5 "Phone, and 6, "Movie." GoldVarb showed that situations where there was unequal power, combined with a low imposition request, and action requested of the address, favored the use of no T/V forms. Situations in which the speaker had social power and in which an object was being requested most favored the use of a T-variant. These findings mirror those of the per scenario analysis.

However, it is curious that the social distance variable was selected as significant only for the distribution of the V-variant, not for the T- or 0 -variants. Previous studies have found distance to be an important predictor of how T/V forms are used in Finnish. This outcome can be explained through the use of questionnaire data and the means of analysis. First, Varbrul is a program designed to analyze linguistic variation. Scenarios in 
which the speaker was scripted as addressing someone familiar contained scant variation; speakers almost always addressed the interlocutor with a T-form. Thus, Varbrul was forced to consider other sociopragmatic factors, especially the power factor, to account for variation of the $\mathrm{T} / \mathrm{V}$ forms. This points toward a shortcoming in the data itself, as well as the means of analysis.

Cross-tabulations of the GoldVarb results reveal lack of distinction between the independent variables, as well as a lack of data across all situation types. Thus, it is likely the case that, while a Varbrul analysis offers an interesting way of viewing the request data, which did support the findings as a whole, in this study it did not render results that can be viewed as reliably demonstrating the variability of Finnish T/V forms. The viability of a Varbrul analysis, then, making use of sociopragmatic factors, is questionable at this point; data showing more variability would be necessary to further test this method of analysis. The scripted prompts can be seen as successful in that they showed preferred ways of requesting across a variety of situations, as seen from the congruency in relatively "easy" requests and variation in relatively "difficult" requests. The merits of measuring pragmatic variability through a variation analysis, though, remain unclear in this study.

\section{References}

Blum-Kulka, Shoshana (1982) Learning how to say what you mean in a second language: A study of speech act performance of learners of Hebrew as a second language. Applied Linguistics 3: 29-59.

Blum-Kulka, Shoshana (1990) You don't touch lettuce with your fingers: Parental politeness in family discourse. Journal of Pragmatics 14: 259-288.

Blum-Kulka, Shoshana, Juliane House, and Gabriele Kasper (eds.) (1989) Cross-cultural pragmatics: Requests and apologies. Norwood, NJ: Ablex Publishing Corporation.

Brown, Roger, and Albert Gilman (1960) The pronouns of power and solidarity. In Thomas Sebeok (ed.), Style in Language. New York: MIT, pp. 253-276.

Brown, Penelope, and Stephen Levinson (1978) Politeness: Some universals in language usage. In E.N. Goody (ed.), Questions and politeness: Strategies in social interaction. Cambridge: Cambridge University Press, pp. 56-310.

Brown, Penelope, and Stephen Levinson (1987) Politeness: Some universals in language usage. Cambridge: Cambridge University Press.

Byon, Andrew Sangpil (2006) The role of linguistic indirectness and honorifics in achieving linguistic politeness in Korean requests. Journal of Politeness Research 2: 247-276.

Cedergren, Henrietta, and David Sankoff (1974) Variable rules: Performance as a statistical reflection of competence. Language 50: 333-355.

Churchill, E. (1999, September). Pragmatic development in L2 request strategies by lower level learners. Presented at Second Language Research Forum, University of Minnesota.

Clyne, Michael, Heinz-Leo Kretzenbacher, Catrin Norrby, and Doris Schüpbach (2006) Perceptions of variation and change in German and Swedish address. Journal of Sociolinguistics 10/3: 287-319.

Dines, Elizabeth R. (1980) Variation in discourse - “and stuff like that.” Language in Society 9.1: 13-31. 
Eelen, Gino (2001) A Critique of Politeness Theories. Manchester: St. Jerome Publishing.

Goffman, Erving (1967) Interaction Ritual: Essays on Face-to-Face Behavior. Garden City, New York: Doubleday, Anchor Books.

Harris, Sandra (2003) Politeness and power: Making and responding to 'requests' in institutional settings. Text 23: 27-52.

Hartford, Beverly, and Kathleen Bardovi-Harlig (1992) Experimental and observational data in the study of interlanguage pragmatics. Pragmatics and Language Learning. Volume 3. Urbana, IL: University of Illinois at Urbana-Champaign, pp. 33-52.

Helasvuo, Marja-Liisa, and Lea Laitinen (2006) Zero person in Finnish. A grammatical resource for constructing human reference. In Marja-Liisa Helasvuo and Lyle Campbell (eds.), Grammar from the human perspective: Case, space and person in Finnish. Amsterdam: John Benjamins Publishing Company.

Lakoff, Robin (1973) The logic of politeness; or minding your p’s and q's. In Papers from the ninth regional meeting of the Chicago Linguistics Society. University of Chicago, pp. 292-305.

Lakoff, Robin (1975). Language and women’s place. New York: Harper and Row.

Lappalainen, Hanna (2004). Variaatio ja sen funktiot. Erään sosiaalisen verkoston jäsenten kielellisen variaation ja vuorovaikutuksen tarkastelua [Variation and its functions]. Helsinki: Suomen Kirjallisuuden Seura.

Lappalainen, Hanna (2006a) Mie vai mää, sinä vai te? Virkaoijoiden kielelliset valinnat itseen ja vastaanottajaan viitattaessa. In Marja-Leena Sorjonen and Liisa Raevaara (eds.), Arjen asiöntia. Keskustelija Kelan tiskin äärellä. Helsinki: Suomen Kirjallisuuden Seura, pp. 241-284.

Lappalainen, Hanna (2006b) Pronominsubjektin käytöstä ja poisjätöstä Kelan asiointikeskusteluissa. In T. Nordlund, T. Onikki-Rantajääskö and T. Suutari (eds.), Kohtauspaikkana kieli. Näkökulmui persoonaan, muutoksiin ja valintoihin. Helsinki: Suomalaisen Kirjallisuuden Seura, pp. 37-64.

Lappalainen, Hanna (2008) Kelan virkailijoiden henkilötunnuspyynnöt Tutkimus rutiininomaisista [Asking for clients' identity number or identity card at Finnish Social Security offices: A study of routinized activities)]. Virittäjä 4: 483-517.

Lavandera, Beatriz (1978) Where does the sociolinguistic variable stop? Language in society 7.2: 171-182.

Leech, Geoffrey. (1983) Principles of pragmatics. London and New York: Longman.

Locher, Miriam (2004) Power and Politeness in Action: Disagreemetns in Oral Communication. Berlin/New York: Mouton de Gruyter.

Meier, A.J. (1995a) Defining politeness: Universality in appropriateness. Language Sciences 17.4: 345-356.

Meier, A.J. (1995b) Passages of politeness. Journal of Pragmatics 4: 381-392.

Milroy, Lesley (1980) Language and social networks. Oxford, UK; New York: Blackwell.

Muikku-Werner, Pirkko (1993) Impositiivus ja kielellinen variaatio. Julkisten keskustelujen käskyt ja kysymykset kelenopetuksen näkökulmasta. Joensuun yliopiston humanistisia julkaisuja 14. Joensuu.

Niendorf, Mariya (2005) Investigating the future of Finnish congruency: Focus on possessive morphology. Unpublished doctoral dissertation. Bloomington, Indiana: Indiana University, Department of Central Eurasian Studies. 
Nuolijärvi, Pirkko, and Liisa Tiittula (2001) Rakas Tarja ja hyvä ystävä. Puhuttelu minän ja sosiaalisten suhteiden esittämisen keinoina televisiokeskustelussa. Virittäjä 4: 580-601.

Paolillo, John (2002) Analyzing linguistic variation: Statistical models and methods. Stanford, CA: CSLI Publications, Center for the Study of Language and Information.

Paunonen, Heikki (1995) Morphological changes in spoken Finnish possessive forms. Virittäjä 99.4: 501531.

Peterson, Elizabeth (2004) Social appropriateness and language variation: A study of Finnish requests. Unpublished doctoral dissertation, Department of General Linguistics, Bloomington, Indiana: Indiana University.

Sankoff, David, Sali Tagliamonte, and Eric Smith (2005) Goldvarb X: A variable rule application for Macintosh and Windows. New York: Department of Linguistics, University of York.

Sankoff, Gillian (1974) A quantitative paradigm for the study of communicative competence. In R. Bauman and J. Sherzer (eds.), Explorations in the ethnography of speaking. Cambridge University Press, pp. 18-49.

Seppänen, Eeva-Leena (1989) Henkilöön viittaaminen puhetilanteessa. In Auli Hakulinen (ed.), Suomalaisen keskustelun keinoja I. Kieli 4. Helsinki: The University of Helsinki, Department of Finnish, pp. 195-222.

Sorjonen, Marja-Leena (2001) Responding in conversation: A study of response particles in Finnish. Amsterdam: John Benjamins Publishing Company.

Statistics Finland. (2010) Finland in figures. Retrieved March 15, 2010 from http://www.stat.fi/index_en.html.

Tagliamonte, Sally (2006) Analysing Sociolinguistic Variation. Cambridge: Cambridge University Press.

Varghese, Manke, and Kristine Billmyer (1996) Investigating the structure of discourse completion tests. Working Papers in Educational Linguistics 12.1: 39-58.

VISK = Auli Hakulinen, Maria Vilkuna, Riitta Korhonen, Vesa Koivisto, Tarja Riitta Heinonen ja Irja Alho (2004) Iso suomen kielioppi, web version 2008. Helsinki: Suomalaisen Kirjallisuuden Seura. Available at http://scripta.kotus.fi/visk URN:ISBN:978-952-5446-35-7

Watts, Richard J., Sachiko Ide, and Konrad Ehlich (eds.) (1992) Politeness in language. Berlin: Mouton de Gruyter.

Yli-Vakkuri, Valma (2005) Politeness in Finland: Evasion at all costs. In Leo Hickey and Miranda Stewart (eds.), Politeness in Europe. Clevedon, UK: Multilingual Matters.

\section{Appendix A}

\section{Coding categories for glosses (from Sorjonen 2001)}

$1^{\text {st }}$ person ending

$2^{\text {nd }}$ person ending

$3^{\text {rd }}$ person ending 


\section{Case endings}

A slash is used to indicate where the choice in a case ending vowel would depend on the vowel(s) present in the stem.

\section{Case Ending}

accusative no ending, $-n,-t$

partitive $-a / \ddot{a}$, $-t a / \ddot{a}$, $-t t a / \ddot{a}$

$\begin{aligned} \text { Abbreviation } & \text { Approximate meaning } \\ \text { ACC } & \text { object } \\ \text { PAR } & \text { partitiveness }\end{aligned}$

Other abbreviations

FOR formal

INF infinitive

POS possessive

Q interrogative

SG singular

PL plural

\section{Appendix B}

The ODCT scenarios in Finnish (note: All are presented with the T-variant)

1) Työskentelet tele-alan yrityksessä. Pyydät sihteeriä ottamaan puhelinviestisi sillä aikaa kun olet kokouksessa. Hän on ollut työssä osastollasi viisi vuotta.

2) Olet sihteeri ja olet työskennellyt yrityksessä kolme viikkoa. Tänään haluat tavata ystäväsi lounaalla ja pyydät lupaa lähteä normaalia aikaisemmin.

3) Odotat bussia lähellä asuntoasi. Sinulla on vanha aikataulu, etkä tiedä milloin bussi tulee. Nainen, joka asuu samassa talossa kuin sinä, on bussipysäkillä, mutta ette tunne toisianne. Hän selailee uutta aikataulua.

4) Olet valmistamassa päivällistä kotonasi ja huonetoverisi/aviopuolisosi/ poikaystäväsi/tyttöystäväsi on keittiössä. Tarvitset suolaa ja kätesi ovat rasvaiset.

5) Olet bussissa matkalla keskustaan ja kännykästäsi on virta loppunut. Sinun pitää soittaa ystävällesi sopiaksesi mihin menisitte kahville.Vieressäsi istuu sinun ikäisesi henkilö, jolla on kännykkä.

6) Olet elokuvateatterin katsomossa. Kaksi nuorta tyttöä puhuu edessäsi, etkä kuule mitä elokuvassa sanotaan. Päätät sanoa asiasta heidän äidilleen.

7) Olet syömässä ravintolassa. Olet jo aloittanut ruokailun ja haluat tilata vettä. Tarjoilija tulee pöytään.

ELIZABETH PETERSON is a University Lecturer in the Department of Modern Languages at the University of Helsinki. She has a Ph.D. in general linguistics from Indiana University, Bloomington. Her research interests include politeness, pragmatic variation, discourse markers, and language variation and change. Address: Department of Modern Languages/English, University of Helsinki, PL 24 (Unioninkatu 40B, 6th kerros), 00014 University of Helsinki, Finland. E-mail: elizabeth.peterson@helsinki.fi 